\title{
Hypopigmentation after intra-articular corticosteroid injection
}

\author{
Aman Gupta, ${ }^{1}$ Megha Garg, ${ }^{2}$ Nameirakpam Johnson, ${ }^{1}$ Pandiarajan Vignesh ${ }^{1}$
}

${ }^{1}$ Allergy Immunology Unit, Advanced Pediatrics Centre, Postgraduate Institute of Medical Education and Research, Chandigarh, India ${ }^{2}$ Dermatology, Medens Multispeciality Clinics, Panchkula, Haryana, India

Correspondence to Dr Aman Gupta, drgupta_aman@yahoo.com

Accepted 5 March 2019
Check for updates

C) BMJ Publishing Group Limited 2019. No commercial re-use. See rights and permissions. Published by BMJ.

To cite: Gupta A, Garg M, Johnson N, et al. BMJ Case Rep 2019:0:e228921. doi:10.1136/bcr-2018228921

\section{DESCRIPTION}

Intra-articular corticosteroid injection may be associated with several adverse effects. ${ }^{1}$ Identification of aetiology of hypopigmentation in a child with juvenile idiopathic arthritis is important to guide appropriate therapy. A 10-year-old girl, with polyarticular juvenile idiopathic arthritis, presented with hypopigmentation over right wrist joint of 1 -week duration. She had received oral naproxen for 6 weeks followed by weekly subcutaneous methotrexate $\left(15 \mathrm{mg} / \mathrm{m}^{2}\right)$. Triamcinolone acetonide $(40 \mathrm{mg})$ was injected in her right wrist joint for persistent arthritis. Four weeks later, hypopigmentation was noted (figure 1). Systemic examination was unremarkable. Her blood counts, renal and liver function tests were normal. Hypopigmentation in our patient was attributed to intra-articular corticosteroid injection given the temporal association.

Triamcinolone injection into inflamed joints is a routine practice for paediatric rheumatologists. It may often result in local side effects including atrophy, calcification, hyperpigmentation and hypopigmentation of overlying skin. ${ }^{1}$ Pigmentary changes after steroid injection in adults with tenosynovitis have also been reported. ${ }^{2}$ Hypopigmentation is usually seen after a few weeks of corticosteroid injection and may be more prominent in dark skinned individuals. ${ }^{3}$ It is more frequently seen in small or superficial joints as compared with large joints. Function or number of melanocytes may be affected though the exact mechanism underlying hypopigmentation due to injected corticosteroids

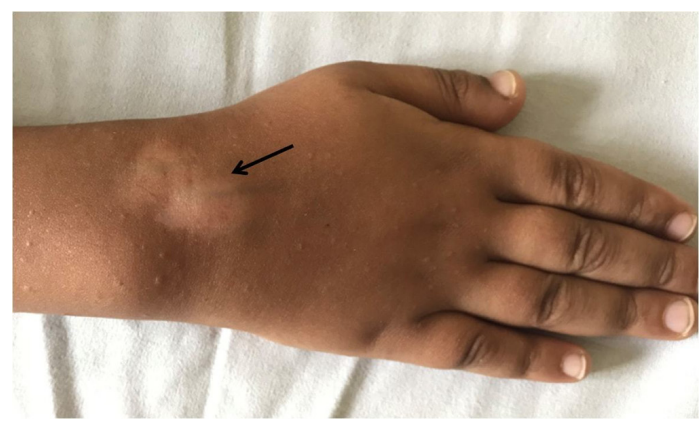

Figure 1 Hypopigmentation over the right wrist joint noted 4 weeks after intra-articular triamcinolone injection. remains unknown. ${ }^{3}$ Hypopigmentation may depend on the concentration and preparation of the injected corticosteroid. Triamcinolone is more likely to cause local side effects because of its high density, low solubility and high tendency to aggregate. There is no specific therapy and hypopigmentation usually resolves after a few months. ${ }^{3}$ A careful history can elicit the cause of hypopigmentation in these patients. Patients need to be counselled and educated regarding the adverse effects that may be seen after intra-articular corticosteroid injections, including hypopigmentation. Paediatric rheumatologists and dermatologists need to be aware of this uncommon outcome as it can affect the diagnostic plan and therapeutic measures.

\section{Learning points}

Hypopigmentation may be seen after a few weeks of intra-articular corticosteroid injection.

- Hypopigmentation following intra-articular corticosteroid administration usually resolves after a few months and warrants no specific therapy.

Contributors AG was involved in conception of the work, acquisition, analysis and interpretation of the data, and drafting the work. MG was involved in acquisition and analysis of the data and drafting the work. NJ was involved in interpretation of the data and drafting the work. PV was involved in interpretation of the data and revising the work critically for intellectual content.

Funding The authors have not declared a specific grant for this research from any funding agency in the public, commercial or not-for-profit sectors.

Competing interests None declared.

Patient consent for publication Obtained.

Provenance and peer review Not commissioned; externally peer reviewed.

\section{REFERENCES}

1 Brinks A, Koes BW, Volkers AC, et al. Adverse effects of extra-articular corticosteroid injections: a systematic review. BMC Musculoskelet Disord 2010;11:206

2 Milani C, Lin C. Proximal linear extension of skin hypopigmentation after ultrasound-guided corticosteroid injection for de quervain tenosynovitis: a case presentation. PM R 2018;10:873-6.

3 Firooz A, Tehranchi-Nia Z, Ahmed AR. Benefits and risks of intralesional corticosteroid injection in the treatment of dermatological diseases. Clin Exp Dermatol 1995;20:363-70. 
Copyright 2019 BMJ Publishing Group. All rights reserved. For permission to reuse any of this content visit https://www.bmj.com/company/products-services/rights-and-licensing/permissions/

BMJ Case Report Fellows may re-use this article for personal use and teaching without any further permission.

Become a Fellow of BMJ Case Reports today and you can:

- Submit as many cases as you like

- Enjoy fast sympathetic peer review and rapid publication of accepted articles

Access all the published articles

- Re-use any of the published material for personal use and teaching without further permission

For information on Institutional Fellowships contact consortiasales@bmjgroup.com

Visit casereports.bmj.com for more articles like this and to become a Fellow 